\title{
Fluctuation in Germination on Exposure to Salt Stress in Trifolium Alexandrium L. in Cultivars
}

\author{
Jyoti Khanduri $^{1} \cdot$ Vimlendu Bhushan Sinha $^{2} \cdot$ Indra Rautela $^{3} \cdot$ Rajesh Rayal $^{4} \cdot$ Manish Dev \\ Sharma $^{1^{*}}$ \\ ${ }^{1}$ Department of Biotechnology, School of Basic and Applied Sciences, Shri Guru Ram Rai University, Patel \\ Nagar, Dehradun-248001, Uttarakhand, INDIA \\ ${ }^{2}$ Department of Biotechnology, School of Engineering and Technology, Sharda University, Greater Noida, Uttar \\ Pradesh-201310, India \\ ${ }^{3}$ Department of Biotechnology, School of Applied and Life Sciences, Uttaranchal Univesity, Dehradun-248001, \\ Uttarakhand \\ ${ }^{4}$ Department of Zoology, School of Basic and Applied Sciences, Shri Guru Ram Rai University, Patel Nagar, \\ Dehradun-248001, Uttarakhand, INDIA
}

*Corresponding author Email: sharma.manishdev@gmail.com

Received: 30.5.2021; Revised: 26.8.2021; Accepted: 29.9.2021

OSociety for Himalayan Action Research and Development

\begin{abstract}
Trifolium alexandrinum L. is a leguminuous plant having tremendous nutritional values associated with it to be utilized as cattle feed. The germination is affected by different factors and one of them being the water absorption capacity of seeds for initial germination. In our study three cultivars of $T$. alexandrinum viz. BB1 BB2 BB3 were selected and their corresponding seeds were germinated under $\mathrm{Na}_{2} \mathrm{SO}_{4}$ stress. The salt concentration chosen for the study ranged from $0 \mathrm{mM}, 25 \mathrm{mM}, 50 \mathrm{mM}, 75 \mathrm{mM}, 100 \mathrm{mM}$, and $150 \mathrm{mM}$. The study revealed that the salt concentration $0 \mathrm{mM}, 25 \mathrm{mM}, 50 \mathrm{mM}$ were not having pronounced effect but upon increasing the salt concentration the rate of germination decreased and hence the radical, plumule and cotyledonary leaf also was drastically reduced.
\end{abstract}

Key words: Trifolium alexandrinum; Clover; Germination; Salt stress; Adverse condition; Environmental stress.

\section{Introduction}

Environmental stress retards plant growth and cause dip in crop productivity and the reports suggests its effect in about $20 \%$ of the irrigated land worldwide (Qadir et al. 2014; Mujeeb-Kazi et al. 2019; Sehrawat et al. 2019; Wang et al. 2019). Plants are able to survive during adverse conditions by the method called as acclimatization and is achieved by the plant with different modification for metabolic processes (Sinha et al. 2014a; Sinha et al. 2018). Salt stress causes water unavailability in the irrigated farms and as a result different osmotic changes becomes visible causing unfavorable condition for plant survival (Acosta-Motos et al. 2017; MujeebKazi et al. 2019).

Salinity is not always detrimental for the plants but in some cases it may also enhance flowering and longer root formation which in turn will help in abiotic stress tolerance development for the plants by the process called adaptation and may also cause faster development (Kumar et al. 2009; Joshi et al. 2018). Salinity effect is different for different stages of the plant and also depends upon the time for which plant has been expose to adverse saline conditions (James et al. 2011; Sinha et al. 2014b; Hnilickova et al. 2019). All the stages of plants are not affected with 
similar toxicity level due to salinity exposure but the metabolic functions experience deviation from the normal one (Hasegawa, 2013; Lekklar et al. 2019; Mulat and Sinha, 2020a). The roots are regarded as the connector between plants machinery determining water uptake, cell expansion etc. and if it malfunctions then plants survival becomes impossible (Munns and Tester, 2008). Salt stress elevates ionic changes and is able to push the plant move towards senescence by disturbing the photosynthetic efficiency of the plant (de Freitas et al. 2019).

Germination of seed is difficult but the seed dormancy may be broken by salinity exposure when used in low concentration (Sinha et al. 2018). The seed vigor or imbibition potential of the seeds can never be generalized but if measured in terms of percentage germination can provide some idea about the seed quality. In case of legumes, germination of seeds is not difficult but influenced by salinity (Mulugeta and Sinha, 2020). Trifolium belongs to Fabaceae and is known as one of the important forage cultivated in the temperate belt worldwide (Williams et al. 2019). However, Trifolium species are adapted in different ecological places experiencing fluctuation in temperature (Guzmán-Ortiz et al. 2019)

The genus has found its adaptability in a number of ecological zones including the semi-arid places which experiences different fluctuating temperature (Annicchiarico et al. 2011). Trifolium alexandrinum $\mathrm{L}$. is one of the important and popular forage for the cattle and is regarded due to the properties of digestibility, mineral content richness etc (Laghari et al. 2000; Garg et al. 2016). The plant can well be used for studying and then eyeing its growth in saline regions which can reduce the burden on vehicles for transportation in those regions where it is not grown but cattle require it. Only a handful of reports are available for Trifolium alexandrinum L. (Bundel Berseem) and pushed the workers for evaluating the capacity cultivars of Bundel Berseem namely BB-1, BB-2 and BB-3 for seed germination for assessing potential applications in saline environment.

\section{Material and Methods}

\section{Seeds viability observance}

The cultivars $\mathrm{BB} 1, \mathrm{BB} 2$ and $\mathrm{BB} 3$ of $T$. alexandrinum were obtained from IGFRI, Jhansi, India. After the seeds were procured the primary task was to access their potential to germinate. Two hundred seeds of each cultivar were kept on moist blotting paper in petri-dishes after soaking the seeds in water.

Seed germination under salinity stress

Thirty seeds each of the procured cultivars were subjected to germination with salt stress of $\mathrm{Na}_{2} \mathrm{SO}_{4}$ in the concentration ranging from 0 $\mathrm{mM}, 25 \mathrm{mM}, 50 \mathrm{mM}, 75 \mathrm{mM}, 100 \mathrm{mM}$, and $150 \mathrm{mM}$ and seeds were germinated following the method available in literature (Sinha et al. 2018; Ghassemabadi et al. 2018). The seeds sets were germinated (in sets of triplicate) in Plant growth chamber with the standard condition of $25 \pm 1{ }^{\circ} \mathrm{C}, 1000$ lux and $16 / 8 \mathrm{~h}$ 
photoperiod. The respective emergence of radicle, plumule and leaves were observed on a daily basis at 10:00 am daily with an interval of $24 \mathrm{~h}$.

\section{Statistical analysis and percentage rate determination}

The percentage seed germination $(\mathrm{G} \%)$ was determined by using the standard formula of (number of germinated seeds $\mathrm{x}$ 100)/ (The total experimental seeds). The Timson's index was determined by the formula Timson's index of germination velocity $=\sum \mathrm{G} / \mathrm{t} ; \mathrm{G}=$ Seed percentage germination per day interval; $t=$ germination period (Goro and Sinha, 2020). The obtained or recorded values of the experiment was analysed by ANOVA using Crop Stat version 7.2.3, IRRI, Philippines.

\section{Results}

Potential of seeds germination verification
The seeds when germinated on petri-dishes were able to germinate and showed germination percentage close to $95 \%, 94 \%$ and $97 \%$ for BB1, BB2 and BB3 respectively.

Effects of sodium sulphate $\left(\mathrm{Na}_{2} \mathrm{SO}_{4}\right)$ stress on radicle appearance

The germination percentages for controlled set was found high in the range close to $95 \%$ and the TI was found $80.8-82.3$. The radicle was found to appear almost on a similar rate for the cultivars BB1, BB2, and BB3 at $25 \mathrm{mM}$ salt stress. The salt concentration when raised to $150 \mathrm{mM}$, a decrease was observed. The highest G\% of 95.6 was observed for control of BBB2 and the lowest 50.1 for $150 \mathrm{mM}$ salt stress in BB3. The $\mathrm{G} \%$ at $75 \mathrm{mM}$ and $100 \mathrm{mM}$ was found almost in the similar range and the TI was also in the comparable range. The result for radicle appearance in the experiment has been reported in Table 1; Figure 1

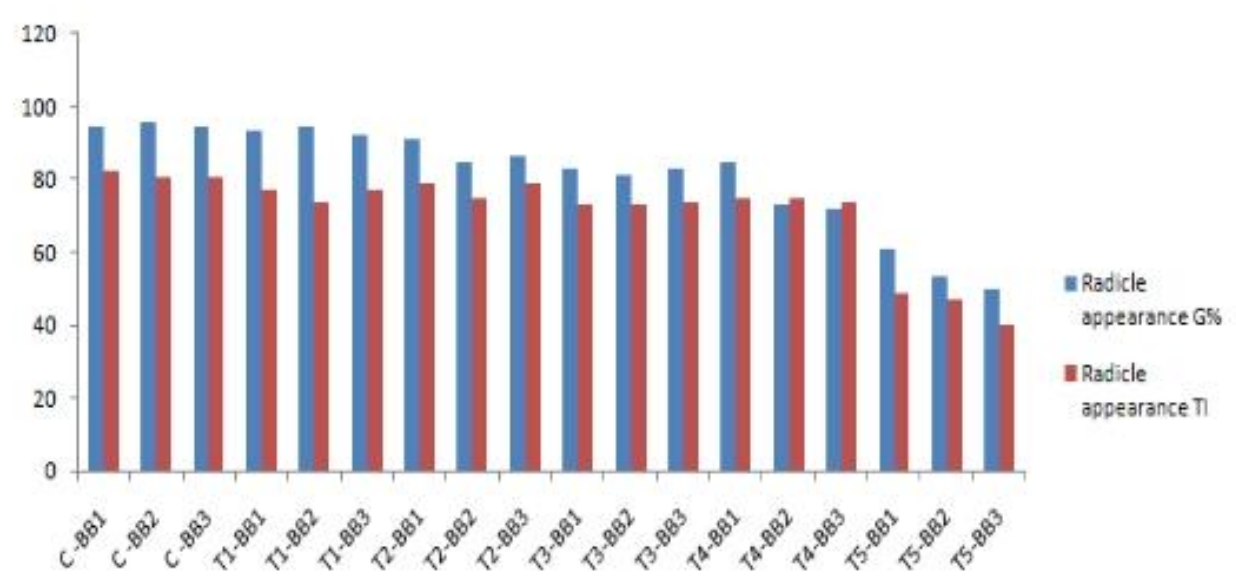

Figure 1: Seed Germination and Timson's index of Radicle appearance of T. alexandrinum Cultivars

\section{Effects of sodium sulphate $\left(\mathrm{Na}_{2} \mathrm{SO}_{4}\right)$ stress} on plumule appearance

The control set showed germination percentage in the range of 87.6-89.1 and the TI was observed between 54.9-57.1. At lower salt stress exposure of $25 \mathrm{mM}$ and $50 \mathrm{mM}$ the G\% and TI of all the tested cultivars were for all the cultivars were comparable just like the radical results From $75 \mathrm{mM}$ salt stress the salt stress effect stared to perceive signals and G\% 
and TI were reducted in the range of 78.6-84.5 and 55.2-54.8 respectively. The $150 \mathrm{mM}$ salt concentration depicted significant decrease in

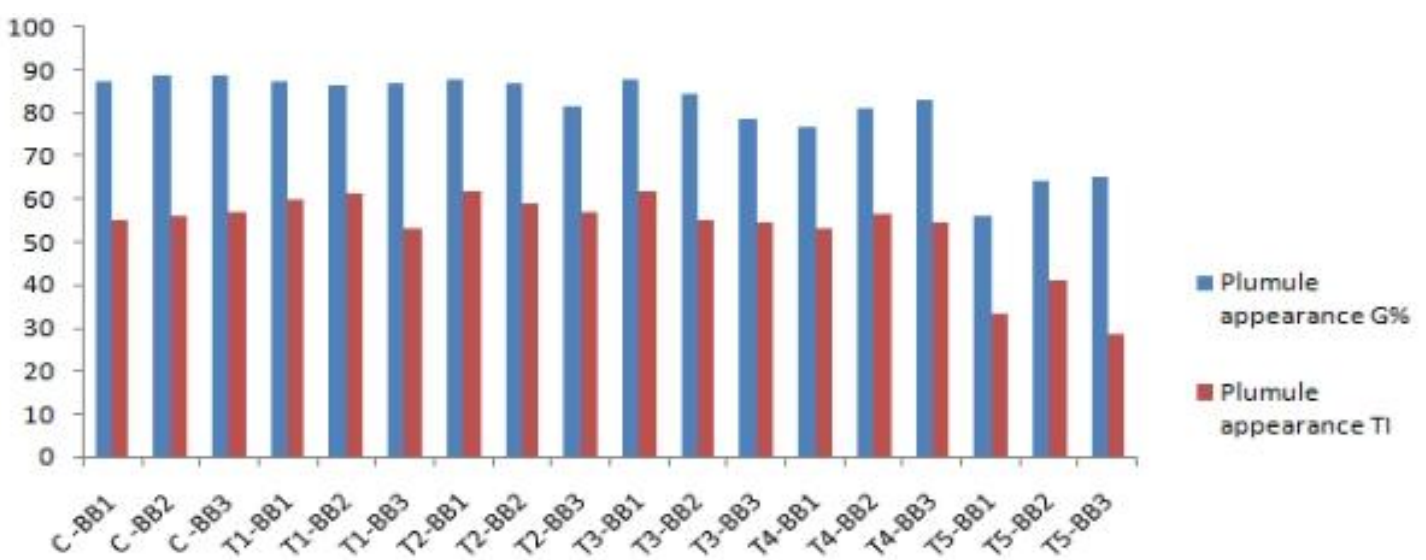

Figure 2: Seed Germination and Timson's index of Plumule appearance of T. alexandrinum Cultivars

Effects of sodium sulphate $\left(\mathrm{Na}_{2} \mathrm{SO}_{4}\right)$ stress on cotyledonary leaf appearance

The appearance of cotyledonary leaves is directly dependent upon the appearance rate of plumule. The G\% exhibited a range of 65.287.5 and the TI was found in the range of 28.6-61.8. The lower value of G\% and TI was
TI to as low as 28.6 for BB3 and hence was significantly lower (Table 1; Figure 2). found only because of the directly proportionality of the plumule appearance over leaf appearance. The rate of G\% and TI both were found to be reduced as the salt stress was exposed to higher percentage. LSD@5\% and SE has also been represented for the executed study data (Table 1; Figure 3).

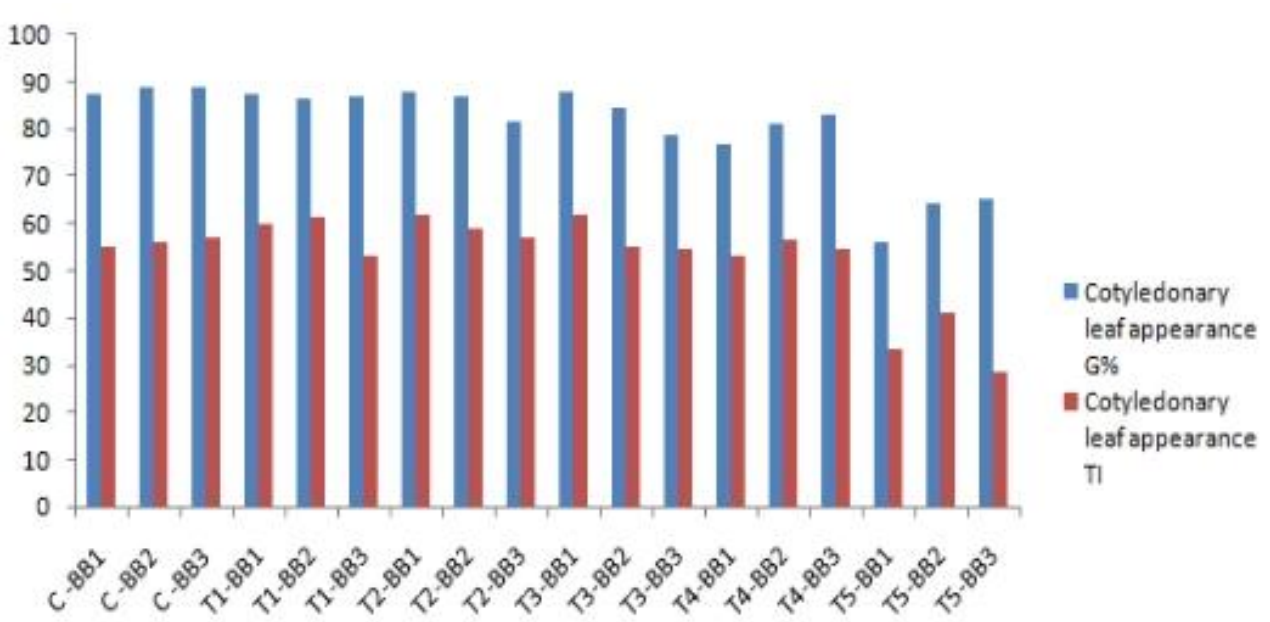

Figure 3: Seed Germination and Timson's index of Cotyledonary leaf appearance of $T$. alexandrinum Cultivars 
Table 1: Effects of $\mathrm{Na}_{2} \mathrm{SO}_{4}$ concentrations on the radicle, plumule and cotyledonary leaf emergence of three cultivars BB1, BB2 and BB3 of T. alexandrinum L. under different concentration.

\begin{tabular}{|c|c|c|c|c|c|c|}
\hline & \multicolumn{2}{|c|}{ Radicle appearance } & \multicolumn{2}{|c|}{ Plumule appearance } & \multicolumn{2}{|c|}{ Cotyledonary leaf appearance } \\
\hline & $\mathrm{G} \%$ & $\mathrm{TI}$ & $\mathrm{G} \%$ & $\mathrm{TI}$ & $\mathrm{G} \%$ & $\mathrm{TI}$ \\
\hline C-BB1 & $94.5^{\mathrm{a}}$ & $82.3^{\mathrm{a}}$ & $87.6^{\mathrm{a}}$ & $54.9^{\mathrm{a}}$ & $87.6^{\mathrm{a}}$ & $54.9^{\mathrm{a}}$ \\
\hline $\mathrm{C}-\mathrm{BB} 2$ & $95.6^{\mathrm{a}}$ & $80.6^{\mathrm{a}}$ & $89.1^{\mathrm{a}}$ & $56.1^{\mathrm{a}}$ & $89.1^{\mathrm{a}}$ & $56.1^{\mathrm{a}}$ \\
\hline C-BB3 & $94.3^{\mathrm{a}}$ & $80.8^{\mathrm{a}}$ & $88.9^{\mathrm{a}}$ & $57.1^{\mathrm{a}}$ & $88.9^{\mathrm{a}}$ & $57.1^{\mathrm{a}}$ \\
\hline $\mathrm{T} 1-\mathrm{BB} 1$ & $93.2^{\mathrm{a}}$ & $77.1^{\mathrm{a}}$ & $87.5^{\mathrm{a}}$ & $59.8^{\mathrm{a}}$ & $87.5^{\mathrm{a}}$ & $59.8^{\mathrm{a}}$ \\
\hline T1-BB2 & $94.5^{\mathrm{a}}$ & $73.9^{\mathrm{a}}$ & $86.7^{\mathrm{a}}$ & $61.3^{\mathrm{a}}$ & $86.7^{\mathrm{a}}$ & $61.3^{\mathrm{a}}$ \\
\hline T1-BB3 & $92.2^{\mathrm{a}}$ & $77.1^{\mathrm{a}}$ & $86.9^{\mathrm{a}}$ & $52.9^{b}$ & $86.9^{\mathrm{a}}$ & $52.9^{\mathrm{b}}$ \\
\hline $\mathrm{T} 2-\mathrm{BB} 1$ & $91.1^{\mathrm{a}}$ & $78.9^{\mathrm{a}}$ & $88.1^{\mathrm{a}}$ & $61.9^{\mathrm{a}}$ & $88.1^{\mathrm{a}}$ & $61.9^{\mathrm{a}}$ \\
\hline $\mathrm{T} 2-\mathrm{BB} 2$ & $84.4^{\mathrm{a}}$ & $74.9^{\mathrm{b}}$ & $87.1^{\mathrm{a}}$ & $58.8^{\mathrm{a}, \mathrm{b}}$ & $87.1^{\mathrm{a}}$ & $58.8^{\mathrm{a}, \mathrm{b}}$ \\
\hline T2-BB3 & $86.3^{\mathrm{a}}$ & $78.8^{\mathrm{a}}$ & $81.8^{\mathrm{a}}$ & $56.8^{\mathrm{b}}$ & $81.8^{\mathrm{a}}$ & $56.8^{\mathrm{b}}$ \\
\hline T3-BB1 & $83.1^{\mathrm{a}}$ & $73.1^{\mathrm{a}}$ & $87.7^{\mathrm{a}}$ & $61.8^{\mathrm{a}}$ & $87.7^{\mathrm{a}}$ & $61.8^{\mathrm{a}}$ \\
\hline T3-BB2 & $81.1^{\mathrm{a}}$ & $73.2^{\mathrm{a}}$ & $84.5^{\mathrm{a}, \mathrm{b}}$ & $55.2^{\mathrm{b}, \mathrm{c}}$ & $84.5^{\mathrm{a}, \mathrm{b}}$ & $55.2^{\mathrm{b}, \mathrm{c}}$ \\
\hline T3-BB3 & $83.1^{\mathrm{a}}$ & $73.8^{\mathrm{b}}$ & $78.6^{\mathrm{b}}$ & $54.8^{c}$ & $78.6^{\mathrm{b}}$ & $54.8^{c}$ \\
\hline T4-BB1 & $84.5^{\mathrm{a}}$ & $74.8^{\mathrm{a}}$ & $76.8^{\mathrm{a}}$ & $53.1^{\mathrm{a}}$ & $76.8^{\mathrm{a}}$ & $53.1^{\mathrm{a}}$ \\
\hline T4-BB2 & $73.3^{\mathrm{b}, \mathrm{c}}$ & $74.6^{\mathrm{a}}$ & $81.1^{\mathrm{a}, \mathrm{b}}$ & $56.3^{\mathrm{b}, \mathrm{a}}$ & $81.1^{\mathrm{a}, \mathrm{b}}$ & $56.3^{\mathrm{b}, \mathrm{a}}$ \\
\hline T4-BB3 & $72.1^{\mathrm{c}}$ & $73.5^{\mathrm{a}}$ & $83.3^{\mathrm{b}}$ & $54.8^{\mathrm{a}}$ & $83.3^{b}$ & $54.8^{\mathrm{a}}$ \\
\hline T5-BB1 & $61.1^{\mathrm{a}}$ & $48.9^{\mathrm{a}}$ & $56.1^{\mathrm{a}}$ & $33.1^{\mathrm{a}}$ & $56.1^{\mathrm{a}}$ & $33.1^{\mathrm{a}}$ \\
\hline T5-BB2 & $53.1^{\mathrm{a}, \mathrm{b}}$ & $47.1^{\mathrm{b}}$ & $64.3^{\mathrm{b}, \mathrm{c}}$ & $41.2^{\mathrm{b}}$ & $64.3^{\mathrm{b}, \mathrm{c}}$ & $41.2^{\mathrm{b}}$ \\
\hline T5-BB3 & $50.1^{\mathrm{b}}$ & $40.0^{\mathrm{c}}$ & $65.2^{c}$ & $28.6^{\mathrm{a}}$ & $65.2^{c}$ & $28.6^{\mathrm{a}}$ \\
\hline SE & 2.6 & 0.9 & 1.9 & 0.9 & 1.9 & 0.9 \\
\hline $5 \% \mathrm{LSD}$ & 7.4 & 2.3 & 6.1 & 3.4 & 6.1 & 3.4 \\
\hline
\end{tabular}

The code refers to $\mathrm{C}=$ control; $\mathrm{T} 1=25 \mathrm{mM}$ stress; $\mathrm{T} 2=50 \mathrm{mM}$ stress; $\mathrm{T} 3=75 \mathrm{mM}$ stress; $\mathrm{T} 4=100$ $\mathrm{mM}$ stress; T5= 150mM stress; BB1, BB2, BB3 corresponds to the cultivar; TI: Timson's index; G\%: Germination percentage.

\section{Discussion}

Germination of seed in field represents one of the most important concept which determines productivity. When plants are subjected to abiotic stress like temperature regimes, light stress, salt stress etc. then the normal growth potential of plants are compromised (Aslam et al. 2010; Sinha et al. 2014c; Auwal et al. 2016; Talaat, 2019). Salt stress destroys productivity and also affects the seeds which in future cause germination delays thereby causing complexities in optimum performance by the plants (Safdar et al. 2019). The water uptake potential of the seeds is affected due to salt stress and our experiments were clearly able to find the difference between the germination of different cultivars of the subject seeds. Only a handful of reports are available on Trifolium for its assessment of germination level and thus, the idea was perceived with curiosity. The germination percentage of all the control sets were found constant and fastest which is 
an ideal for any experiment (Sinha et al. 2018). About fifty percent seeds germinated without difficulty upto $75 \mathrm{mM}$ stress and thus indicates only moderate affect on seeds germination which follows the same pattern based on literature on salinity stress on different seeds germination (Yadav et al. 2019; Jha et al. 2019). When the seeds were subjected to higher range salt stress the germination was hampered and this must have been the result of toxity influx in seed due to salt imbibition and the same pattern is also documented for many species (Auwal et al. 2016; Sozharajan and Natarajan, 2016). Thus, it becomes evident that higher salt concentration becomes a poison for the plant at any critical life stage of the plant and if they becomes acute then they are able to destroy the metabolic functions of the plant's machinery and thus, loss in optimum growth and development of the plant (Liang et al. 2018). It becomes also clarified that if the seeds are not able to produce cotyledonary leaves or even after producing it shows wilting then food synthesis in plant is compromised which leads to the death of the plant at initial level only (Ibrahim et al. 2016; Ashraf et al. 2018). Thus, the question is how do the plant survive then? And the answer provided by our study is whenever plants or seeds are subjected to salt stress then they modify the machinery in such a way that the metabolic rates are functional and are able to develop long roots (Pinheiro et al. 2018). Our study is amongst the pioneer ones in attempting seed germination aspect of Trifolium and holds importance in terms of forage study.

\section{Conclusion}

The outcome of our work confirms interlinking of $\mathrm{TI}$ and germination when subjected to salt stress. Our study has also entrusted that whenever the salt accumulation increases it becomes toxic and disturbs the optimum growth of the seeds and germination being the most critical in plant's life stage is the most affected one. However, low salt concentration was unable to show significant variation in germination and hence points towards synergistic effect in growth and development of plants from seed germination stage itself.

\section{Conflicts of interest}

The authors declare none.

\section{Acknowledgement}

The authors thank IGFRI for kind provision of seeds and Department of Biotechnology, School of Basic and Applied Sciences, Shri Guru Ram Rai University, Patel Nagar Dehradun for providing space and chemicals for the work.

\section{References}

Acosta-Motos J, Ortuño M, Bernal-Vicente A, Diaz-Vivancos P, Sanchez-Blanco M and Hernandez J (2017) Plant Responses to Salt Stress: Adaptive Mechanisms. Agronomy. doi: 10.3390/agronomy7010018

Annicchiarico P, Pecetti L, Abdelguerfi A, Bouizgaren A, Carroni A.M, Hayek T, M'Hammadi Bouzina M, Mezni M (2011) Adaptation of landrace and variety germplasm and selection strategies for lucerne in the Mediterranean basin, Field Crops Research, 120 (2): 283-291, 
Ashraf MA, Akbar A, Askari SH, Iqbal M, Rasheed R and Hussain I (2018) Recent advances in abiotic stress tolerance of plants through chemical priming: An overview. Adv Seed Priming 51-79

Aslam M, Sinha VB, Singh RK, Anandhan S, Pande V and Ahmed Z (2010) Isolation of cold stress-responsive genes from Lepidium latifolium by suppressive subtraction hybridization. Acta Physiol Plant 32: 205-210

Auwal A, Ibrahim JA and Sinha VB (2016) Response of Wheat Seeds Grown under $\mathrm{NaCl}$ and $\mathrm{ZnCl} 2$ Stress . Res J Sci Technol 8: 77

de Freitas PAF, de Carvalho HH, Costa JH, Miranda R de S, Saraiva KD da C, de Oliveira FDB, Coelho DG, Prisco JT and Gomes-Filho E (2019) Salt acclimation in sorghum plants by exogenous proline: physiological and biochemical changes and regulation of proline metabolism. Plant Cell Rep. doi: 10.1007/s00299-019-02382-5

Garg, R., Shankar, R., Thakkar, B., Kudapa, H., Krishnamurthy, L., Mantri, N., Varshney, R.K., Bhatia, S. and Jain, M. (2016) Transcriptome analyses reveal genotype- and developmental stage-specific molecular responses to drought and salinity stresses in chickpea. Sci. Rep. 6, 19228.

Ghassemabadi FH, Eisvand HR and Akbarpour OA (2018) Evaluation of salinity tolerance of different clover species at germination and seedling stages. Iran J Plant Physiol 8: 24692477

Goro, M and Sinha, V (2020). Seed germination responses for varying KNO3 and NaNO3 stress in Trifolium alexandrinum. L cultivars. Biocatalysis and Agricultural Biotechnology. $25 . \quad 101618$. 10.1016/j.bcab.2020.101618.

Hasegawa PM (2013) Sodium (Na+) homeostasis and salt tolerance of plants. Environ Exp Bot. doi: 10.1016/j.envexpbot.2013.03.001
Hniličková H, Hnilička F, Orsák $\mathrm{M}$ and Hejnák V (2019) Effect of salt stress on growth, electrolyte leakage, $\mathrm{Na}^{+}$ and $\mathrm{K}^{+}$content in selected plant species. Plant, Soil Environ 65: 90-96

Ibrahim JA, Auwal A and Sinha VB (2016) Physiological response of wheat seeds grown under $\mathrm{NaCl}$ and $\mathrm{HgCl}_{2}$ stress. Int J Sci Rep. 2: 130-135

James RA, Blake C, Byrt CS and Munns R (2011) Major genes for $\mathrm{Na}+$ exclusion, Nax1 and Nax2 (wheat HKT1;4 and HKT1;5), decrease Na+ accumulation in bread wheat leaves under saline and waterlogged conditions. J Exp Bot 62: 2939-2947

Jha UC, Bohra A, Jha R and Parida SK (2019) Salinity stress response and 'omics' approaches for improving salinity stress tolerance in major grain legumes. Plant Cell Rep 38: 255-277

Joshi R, Sahoo KK, Tripathi AK, Kumar R, Gupta BK, Pareek A and SinglaPareek SL (2018) Knockdown of an inflorescence meristem-specific cytokinin oxidase - OsCKX2 in rice reduces yield penalty under salinity stress condition. Plant Cell Environ 41: 936-946

Kumar G, Purty RS, Singla-Pareek SL and Pareek A (2009) Maintenance of stress related transcripts in tolerant cultivar at a level higher than sensitive one appears to be a conserved salinity response among plants. Plant Signal Behav 4: 431-434

Lekklar C, Chadchawan S, Boon-Long P, Pfeiffer W and Chaidee A (2019) Salt stress in rice: multivariate analysis separates four components of beneficial silicon action. Protoplasma 256: $331-347$

Laghari H.H, Channa A.D, Solangi A.A and Soomro S.A (2000) Comparative digestibility of different cuts of berseem (Trifolium alexandrinum) in sheep. Pakistan Journal of biological Sciences. 3(11): 1938-1939.

Liang W, Ma X, Wan P and Liu L (2018) Plant salt-tolerance mechanism: A 
review. Biochem Biophys Res Commun 495: 286-291

Mujeeb-Kazi A, Munns R, Rasheed A, Ogbonnaya FC, Ali N, Hollington P, Dundas I, Saeed N, Wang R and Rengasamy P, et al (2019) Breeding strategies for structuring salinity tolerance in wheat, 1st ed. Adv Agron. doi: 10.1016/bs.agron.2019.01.005

Mulat MW and Sinha VB (2020) Identification and characterization of Dof in Tef [Eragrostis tef (Zucc.) Trotter] using in silico approaches. Gene Reports 19: 100590

Munns R and Tester M (2008) Mechanisms of salinity tolerance. Annu Rev Plant Biol 59: 651-81

Pinheiro C, Ribeiro IC, Reisinger V, Planchon S, Veloso MM, Renaut J, Eichacker L and Ricardo CP (2018) Salinity effect on germination, seedling growth and cotyledon membrane complexes of a Portuguese salt marsh wild beet ecotype. Theor Exp Plant Physiol 30: 113-127

Qadir M, Quillérou E, Nangia V, Murtaza G, Singh M, Thomas RJ, Drechsel P and Noble AD (2014) Economics of saltinduced land degradation and restoration. Nat Resour Forum. doi: 10.1111/1477-8947.12054

Safdar H, Amin A, Shafiq Y, Ali A, Yasin R, Shoukat A, Hussan MU and Sarwar MI (2019) A review: Impact of salinity on plant growth. Nat Sci 17 : 34-40

Sehrawat N, Yadav M, Sharma AK, Kumar V and Bhat KV (2019) Salt stress and mungbean [Vigna radiata (L.) Wilczek]: effects, physiological perspective and management practices for alleviating salinity. Arch Agron Soil Sci 65: 1287-1301.

Sinha VB, Grover A, Aslam M, Pande V and Ahmed Z (2014b) Isolation and characterization of Ras-related GTPbinding protein (Ran) from Lepidium latifolium L. reveals its potential role in regulating abiotic stress tolerance. Acta Physiol Plant 36: 2353-2360
Sinha VB, Grover A, Singh S, Pande V and Ahmed Z (2014c) Overexpression of Ran gene from Lepidium latifolium $L$. (LlaRan) renders transgenic tobacco plants hypersensitive to cold stress. Mol Biol Rep 41: 5989-5996

Sinha VB, Grover A, Yadav PV and Pande V (2018) Salt and osmotic stress response of tobacco plants overexpressing Lepidium latifolium L. Ran GTPase gene. Indian J Plant Physiol 23: 494-498

Sinha VB, Grover A, Zakwan.Ahmed and Pande V (2014a) Isolation and functional characterization of DNA damage repair protein ( DRT ) from Lepidium latifolium L . Comptes rendus Biol 337: 302-310

Sozharajan R and Natarajan S (2016) Influence of $\mathrm{NaCl}$ salinity on plant growth and nutrient assimilation of Zea mays L. J Appl Adv Res 1: 54

Talaat NB (2019) Abiotic Stresses-Induced Physiological Alteration in Wheat. Wheat Prod Chang Environ 1-30

Wang Y, Zeng X, Xu Q, Mei X, Yuan H, Jiabu D, Sang Z and Nyima T (2019) Metabolite profiling in two contrasting Tibetan hulless barley cultivars revealed the core salt-responsive metabolome and key salt-tolerance biomarkers. AoB Plants 11: 1-14

Williams WM, Verry IM, Ansari HA, Hussain SW, Ullah I and Ellison NW (2019) A Eurasia-wide polyploid species complex involving $6 \times$ Trifolium ambiguum , $2 \times \mathrm{T}$. occidentale and 4 $\mathrm{x} T$. repens produces interspecific hybrids with significance for clover breeding. 1-12

Yadav SP, Bharadwaj R, Nayak H and Mahto $R$ (2019) Impact of salt stress on growth , productivity and physicochemical properties of plants : A Review. 7: 1793-1798 